\title{
Development of Effective Textile-Reinforced Concrete Noise Barrier
}

\author{
Henrik L. Funke ${ }^{1}$, Sandra Gelbrich ${ }^{1} \&$ Lothar Kroll $^{1}$ \\ ${ }^{1}$ Institute of Lightweight Structures, Technische Universität Chemnitz, Chemnitz, Germany \\ Correspondence: Henrik Funke, Institute of Lightweight Structures, Chemnitz University of Technology, \\ Chemnitz, Germany, Tel: 0049-371-53138995. E-mail: henrik.funke@mb.tu-chemnitz.de
}

Received: March 30, 2015

Accepted: April 10, 2015 Online Published: May 6, 2015

doi:10.5539/jmsr.v4n3p33

URL: http://dx.doi.org/10.5539/jmsr.v4n3p33

\begin{abstract}
Thin-walled, high-strength concrete elements exhibiting low system weight and great slenderness can be created with a large degree of lightweight structure using the textile-reinforced, load-bearing concrete (TRC) slab and a shell with a very high level of sound absorption. This was developed with the objective of lowering system weight, and then implemented operationally in construction.

Arising from the specifications placed on the load-bearing concrete slab, the following took place: an adapted fine-grain concrete matrix was assembled, a carbon warp-knit fabric was modified and integrated into the fine concrete matrix, a formwork system at prototype scale was designed enabling noise barriers to be produced with an application-oriented approach and examined in practically investigations within the context of the project. This meant that a substantial lowering of the load-bearing concrete slab's system weight was possible, which led to a decrease in transport and assembly costs.
\end{abstract}

Keywords: textile-reinforced concrete, noise barrier, high-performance concrete, durability

\section{Introduction}

Noise is a consequence of increasing mobility and has a negative effect on both human beings and the environment. The continual rise in traffic density, which grew by more than 70 percent on motor ways between 1980 and 2012 (Lohre et al., 2012), has led to greater noise emissions. Today, this makes sound protection measures more important than ever. It does not matter whether these noise barriers are for major roads, motorways or high-speed sections. For such systems, there are very complex and contain restrictions with regards to load-bearing capacity, serviceability and functionality. Alongside acoustic and mechanical specifications including durability, economic and ecological aspects additionally come to the fore. The objective is savings on resources not just based on optimizing weight and minimizing manufacturing costs but also leading to decreasing expenditure for transport and assembly.

In Germany, about 50 percent of noise barriers are erected in concrete. They are mostly composed of a load-bearing layer made from steel reinforced concrete and a noise-absorbing facing concrete shell set up on one or both sides and made from lightweight concrete. The usual material thickness with the load-bearing concrete layer is about 12 to $15 \mathrm{~cm}$ due to the concrete coverage needed in terms of passive protection against corrosion. Utilising textile reinforced concrete in this case offers great potential for reducing weight and constructing in a resource-efficient and sustainable manner. Textile reinforced concrete is an innovative high-performance composite material consisting of a fine concrete matrix and textile reinforcement (Curbach \& Scheerer, 2011; Funke et al., 2014; Brameshuber, 2006). The development of this new type of composite material has made a construction method available which utilizes reinforcement that is generally not susceptible to corrosion due to environmental influences (e.g. air humidity and chloride) (Curbach et al., 2008; Curbach \& Jesse, 2010). The concrete coverages needed in steel reinforced concrete construction can thus be substantially reduced by employing textile reinforced concrete (Curbach \& Scheerer, 2012; Funke et al., 2013). Just a few millimeters minimum concrete cover is necessary to safeguard the transfer of bonding forces between the fine concrete matrix and the textile reinforcement (Mobasher et al., 2014; Curbach et al., 2013). This means that thin-walled, free-formed surfaces can be created with a great degree of lightweight structure that feature low system weight and great slenderness.

This paper reports the development of a noise barrier, which consists of a load-bearing concrete made of textile reinforced concrete and a noise-absorbent made of a lightweight concrete. An important part of this work is durability and so the lifespan of the noise barrier. 


\section{Materials and Methods}

\subsection{Components for Load-Bearing and Noise-Absorbent Concretes}

Table 1 illustrates the qualitative and quantitative composition of the load-bearing concrete and the noise-absorbent concrete. The load-bearing concrete contains, besides type CEM I $52.5 \mathrm{R}$ Portland cement according to DIN EN 206, pozzolanic fly ash and silica fume as binding agents (Table 1), which have a positive action on both fresh and hardened concrete characteristics in respect of sedimentation slability, durability and mechanical strength. Two quartz sands and dolomite powder are utilized as aggregate or filler. The alkali resistant (AR) glass fibres, which lower the propensity to shrinkage cracking and can enhance first crack tension in the concrete, are $12 \mathrm{~mm}$ long and have a length mass of 45 tex. The high-performance superplasticiser employed has a 30 percent by weight proportion of polycarboxylate ether (PCE). The noise-absorbent concrete has a monodisperse (single particle) aggregate made of round expanded clay in a fraction of 0 to $2 \mathrm{~mm}$.

Table 1. Composition of the load-bearing and the absorber concrete

\begin{tabular}{lcc}
\hline Component & Load-bearing in $\mathrm{kg} / \mathrm{m}^{3}$ & Absorber in $\mathrm{kg} / \mathrm{m}^{3}$ \\
\hline White cement 52.5 R & 495 & 250 \\
Amorphous alumosilicate & 150 & - \\
Quartz sand 0/2 & 310 & - \\
Quartz sand 0/1 & 900 & - \\
Expanded clay & - & 970 \\
Dolomite powder $\left(\mathrm{x}_{5 \mathrm{~B}}=70 \mu \mathrm{m}\right)$ & 190 & - \\
Water & 210 & 150 \\
AR-glass fibres $(12 \mathrm{~mm}$, integral $)$ & 14 & - \\
superplasticizers & 15 & - \\
Water-binder-ratio & 0.38 & 0.60 \\
\hline
\end{tabular}

\subsection{Textile for Textile Reinforced Concrete}

Two layers of a two-dimensional bidirectional warp-knit fabric of carbon were used for the reinforcement of TRC (Figure 1). The warp and weft yarn had a length weight of $3300 \mathrm{~g} / \mathrm{km}(\bumpeq 3300$ tex) and a tensile strength of 1576 MPa. The mesh size of the 15 mass percent impregnated warp-knit fabric (measured by thermogravimetry) was $10.8 \times 18.0 \mathrm{~mm}^{2}$. The warp and weft yarn consisted of 50000 carbon filaments with a diameter of $7 \mu \mathrm{m}$. The degree of reinforcement in concrete was approximately $1.1 \%$ by volume.

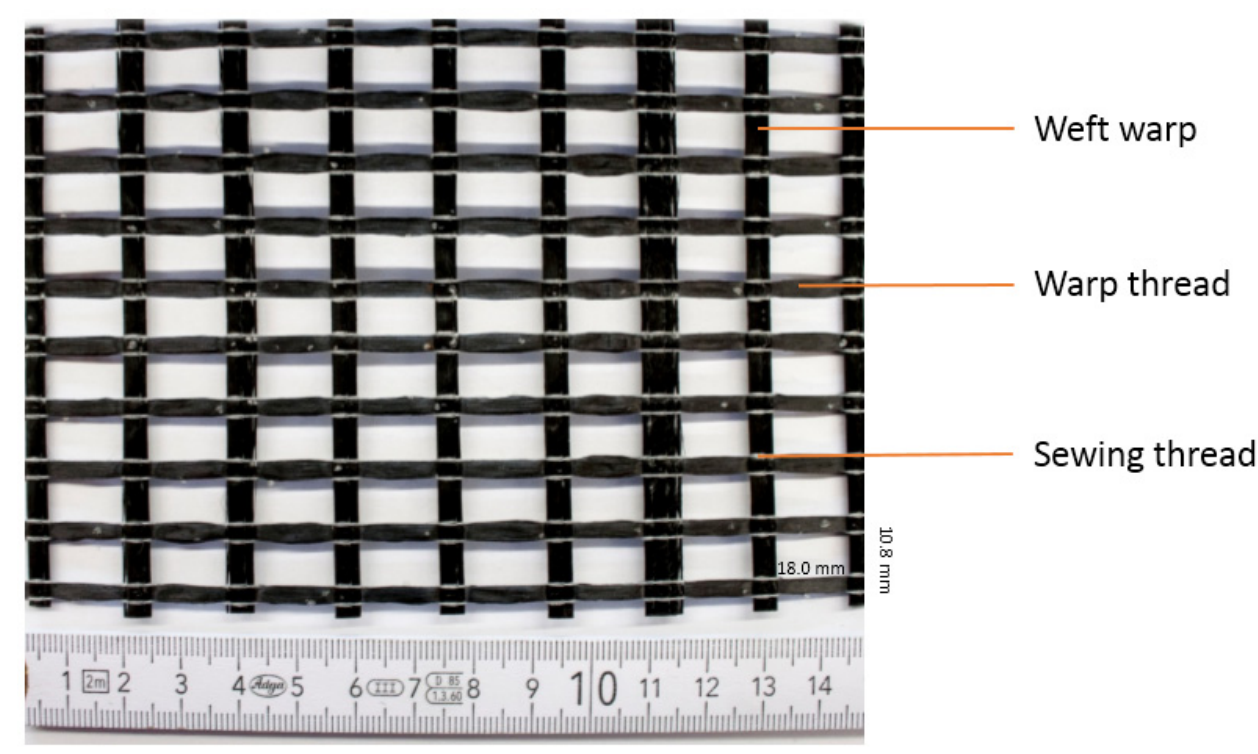

Figure 1. Schematic of the bidirectional warp-knit fabric of carbon fibres 


\subsection{Test Specimens}

Several plates $\left(50 \times 50 \mathrm{~cm}^{2}\right)$ were prepared for the test specimens. In a first step, the absorber concrete was mixed. Thereafter, the fresh absorber concrete was poured into the mold. After this, the fine grained concrete was mixed with the intensive mixer R05T by Erich. The mixing parameters are shown in Table 2.

Table 2. Mixing parameters for fine grained concrete

\begin{tabular}{lcccc}
\hline & component & mixing technology & mixing power in \% & mixing time in s \\
\hline 1st & binders + aggregates & concurrent & 15 & 60 \\
2nd & $75 \%$ of water & sequence & 35 & 90 \\
3rd & super plasticizer & sequence & 35 & 60 \\
4th & residual water & sequence & 40 & 30 \\
5 th & AR-glass fibres & sequence & 40 & 30 \\
\hline
\end{tabular}

Subsequently, the fresh fine grained concrete was applied on the absorber concrete (Figure 2a). Finally, the test plates were demolded after $24 \mathrm{~h}$ (Figure $2 \mathrm{~b}$ ).

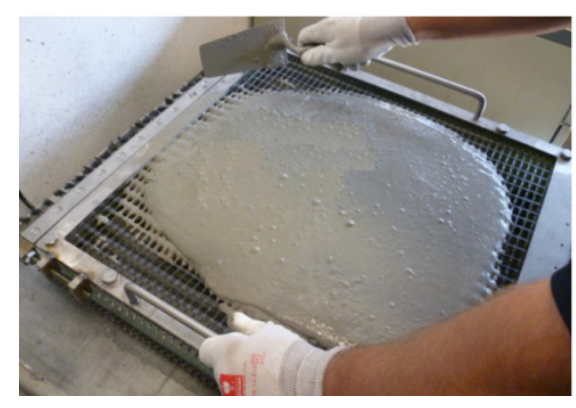

(a) Application of fine grained concrete

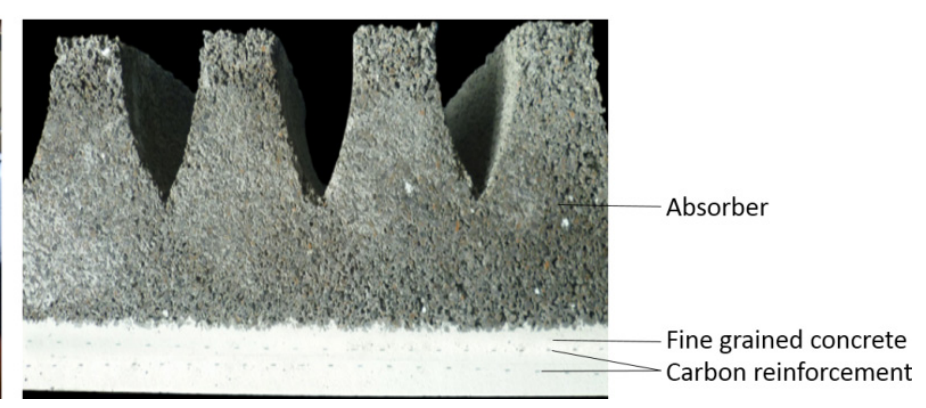

(b) Demolded test plate

Figure 2. Application of fine grained concrete (a) and demolded test plate (b)

\subsection{Test Specimens Test Set-Up for TRC and Absorber}

The samples for the tests to be performed on the hardened concrete were stored dry, according to DIN EN 12390-2. The 3-point bending tensile strength (Figure 3a) was determined by means of the Toni Technik ToniNorm with samples which measured $225 \times 50 \times 15 \mathrm{~mm}^{3}$ (length $\mathrm{x}$ width $\mathrm{x}$ height), based on DIN EN 12390-5. The span width set was $200 \mathrm{~mm}$ and the load speed $100 \mathrm{~N} / \mathrm{s}$ constant. The compressive strength was determined by means of the Toni Technik ToniNorm (load frame $3000 \mathrm{kN}$ ) following DIN EN 12390-3, with cubes having an edge length of $150 \mathrm{~mm}$ (Figure 3b). The pre-load was $18 \mathrm{kN}$.

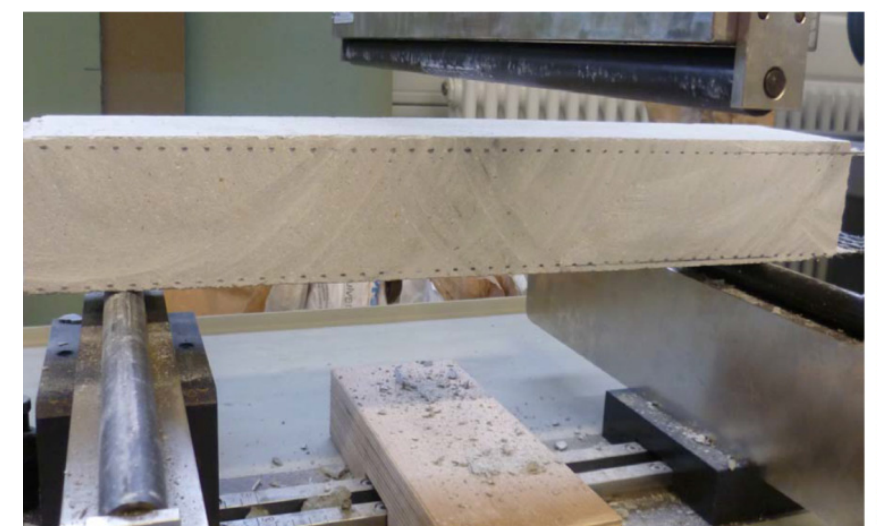

(a) 3-point bending tensile strength

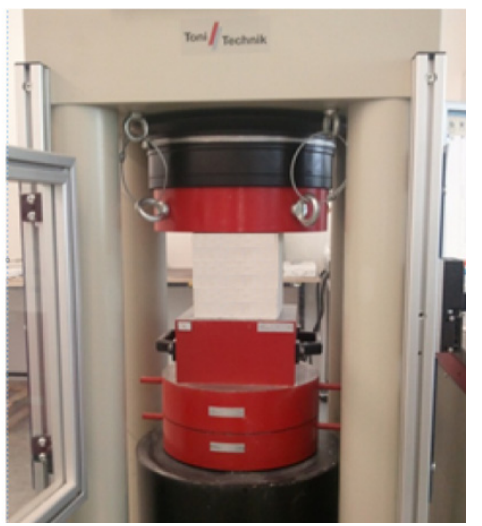

(b) compressive strength

Figure 3. Determination of 3-point bending tensile strength (a) and compressive strength (b) 
To validate the durability of the fine grained concrete, the capillary suction of de-icing solution and freeze thaw test (CDF-Test) was measured by the Schleibinger Freeze-Thaw-Tester with standard agent solution according to the recommendations of RILEM TC 117-FDC (Figure 4).

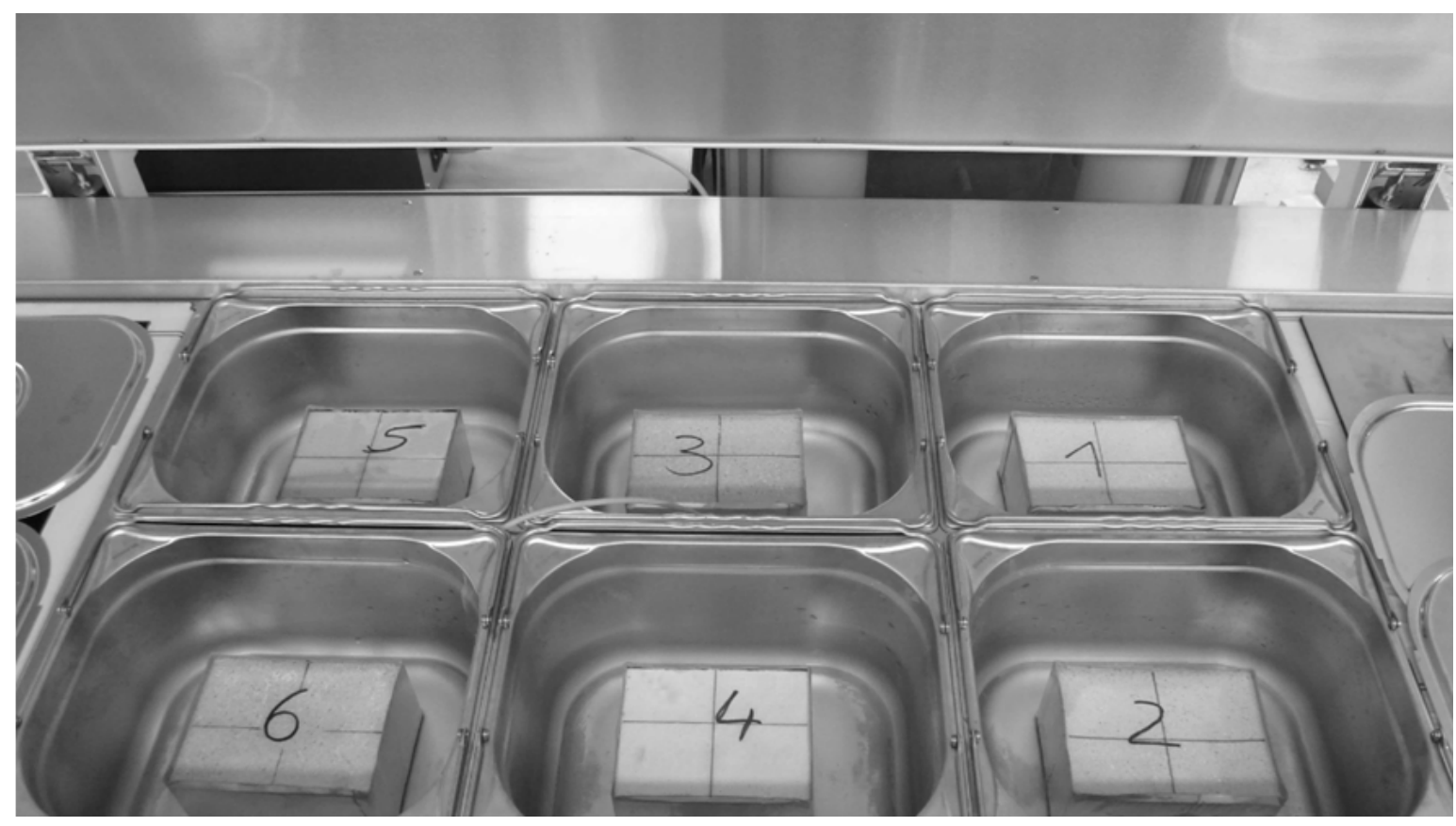

Figure 4. Determination of the capillary suction of de-icing solution and freeze thaw test

\section{Results}

\subsection{Properties of Fresh and Hardened TRC}

Table 3 shows the fresh and hardened concrete characteristics after 28 days. The fresh fine grained concrete possessed great flowability (flow spread $640 \mathrm{~mm}$ ) and corresponded to flow class F6. Using an air content tester, an air content of 2.7 volume percent and a gross geometric density of $2.31 \mathrm{~g} / \mathrm{cm} 3$ were determined in the fresh concrete. A shrinkage channel was utilized to determine the total shrinkage deformation at $0.68 \mathrm{~mm} / \mathrm{m}$. The reason for this high total shrinkage was the high binding agent content and the great chemical and autogenic strength of the hardened concrete at 28 days (gross density: $2.31 \mathrm{~g} / \mathrm{cm} 3$ ) was $83.7 \mathrm{MPa}$; it was $25 \mathrm{MPa}$ after 24 hours. The 3 -point bending tensile strength of the unreinforced concrete was $11.73 \mathrm{MPa}$ after 28 days.

Table 3. Properties of fresh and hardened fine grained concrete

\begin{tabular}{ccc}
\hline characteristic & fresh concrete & hardened concrete \\
\hline geometric bulk density & $2.37 \mathrm{~g} / \mathrm{cm}^{3}$ & $2.31 \mathrm{~g} / \mathrm{cm}^{3}$ \\
flow spread & $640 \mathrm{~mm}$ & - \\
air content & $2.7 \mathrm{Vol} .-\%$ & - \\
linear shrinkage & \multicolumn{2}{c}{$0.91 \mathrm{~mm} / \mathrm{m}$} \\
compressive strength & - & $83.7 \mathrm{MPa}$ \\
3-point bending tensile strength & - & $11.73 \mathrm{MPa}$ \\
\hline
\end{tabular}

In addition, the fine concrete exhibited great durability, which was verified through a successful CDF test with an average weathering of $912 \mathrm{~g} / \mathrm{m}^{2}$ and a relative dynamic modulus of elasticity of 100 percent after 28 freeze-thaw cycles (Table 4). 
Table 4. Examinations of the durability of fine grained concrete

\begin{tabular}{cc}
\hline test method & test value \\
\hline CDF test & $\mathrm{m}_{28}=113 \mathrm{~g} / \mathrm{m}^{2}$ \\
& $\mathrm{R}_{\mathrm{u}, 28}=100 \%$ \\
water penetration depth & $11 \mathrm{~mm}$ \\
\hline
\end{tabular}

Building in 2 layers of carbon meshes in with the flow of forces enabled the 3 point flexural strength to be enhanced to 24.51 MPa (Figure 5). In this case, the first crack tension was 11.21 MPa (Figure 5). By utilizing short fibres with a critical fibre volume content (fibres have a strengthening effect on the matrix) and prestressing the textile reinforcement, an increase in tension without slippage was observed in the concrete after macro-crack formation (see blue shading in Figure 5), i.e. the bending tensile stress was transferred without loss of force from the concrete into the textile reinforcement. Integrating short fibres in the concrete generated a fine crack pattern with a positive action on durability.

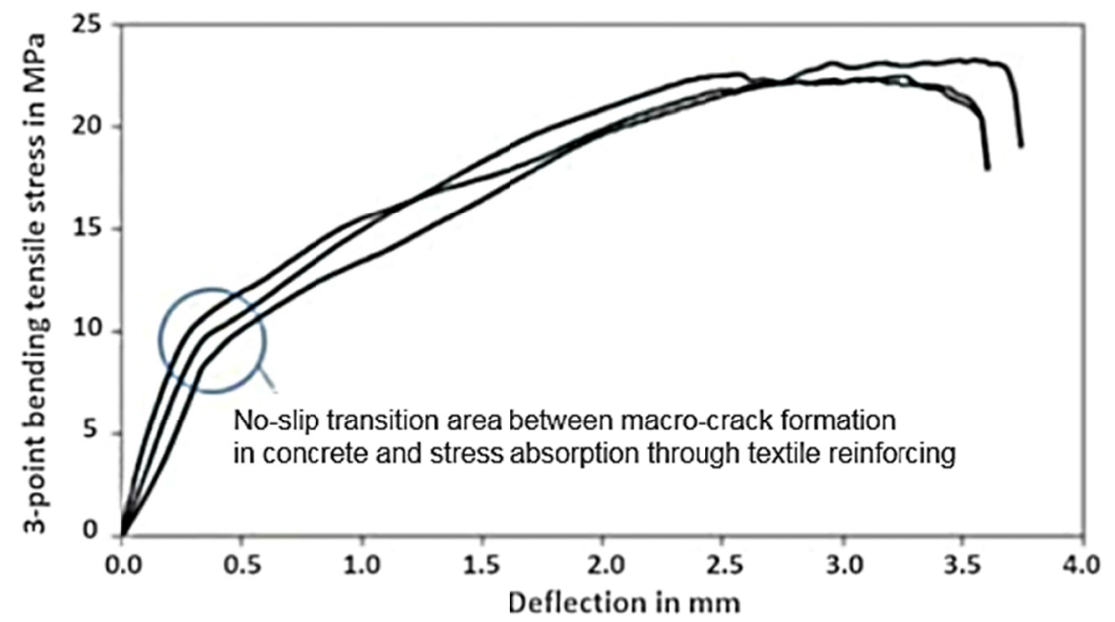

Figure 5. Stress-deflection diagram

\subsection{Noise-Absorbent Concrete}

The noise-absorbent concrete had a gross density of $1.31 \mathrm{~g} / \mathrm{cm} 3$ and a compressive strength of 16.0 MPa (Table 5). A dynamic modulus of elasticity of $17 \mathrm{GPa}$ was determined from the speed of sound using an ultrasonic measurement device.

Table 5. Properties of fresh and noise-absorbent concrete

\begin{tabular}{ccc}
\hline characteristic & fresh concrete & hardened concrete \\
\hline geometric bulk density & $1.53 \mathrm{~g} / \mathrm{cm}^{3}$ & $1.43 \mathrm{~g} / \mathrm{cm}^{3}$ \\
flow spread & $650 \mathrm{~mm}$ & - \\
air content & $11.5 \mathrm{Vol} .-\%$ & 10.4 \\
compressive strength & - & $16.9 \mathrm{MPa}$ \\
3-point bending tensile strength & - & $2.0 \mathrm{MPa}$ \\
\hline
\end{tabular}

The degree of sound absorption was ascertained by means of the reverberation time procedure according to DIN EN ISO 354:2003 with structured test specimens (Figure 6b). The results of this test showed that the degree of sound absorption is more than 0.7 at a frequency of $160 \mathrm{~Hz}$ (Figure 6a). The first local maximum sound absorption $(\alpha=1)$ was found at a frequency of $350 \mathrm{~Hz}$. The decrease in sound absorption between 600 and $1000 \mathrm{~Hz}$ after 800 
$\mathrm{Hz}$ means that great sound particle velocity prevails in this area. These types of curve progressions occur comparatively often with mono-modular and porous aggregate materials. They are indicative of insufficient flow resistance adaptation. The result is that the noise absorber acts like a resonator. Based on these measurements, the noise absorbent shell met the conditions for sound group 4 (highly absorbent).

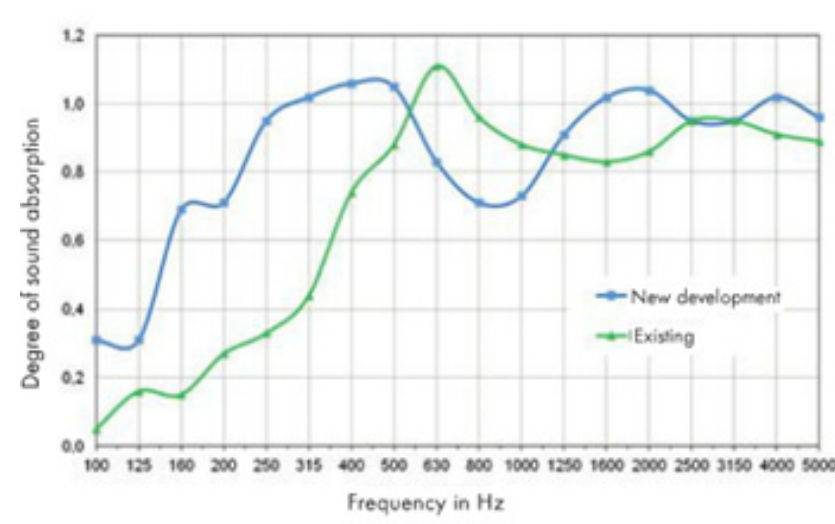

(a) Degree of sound absorption

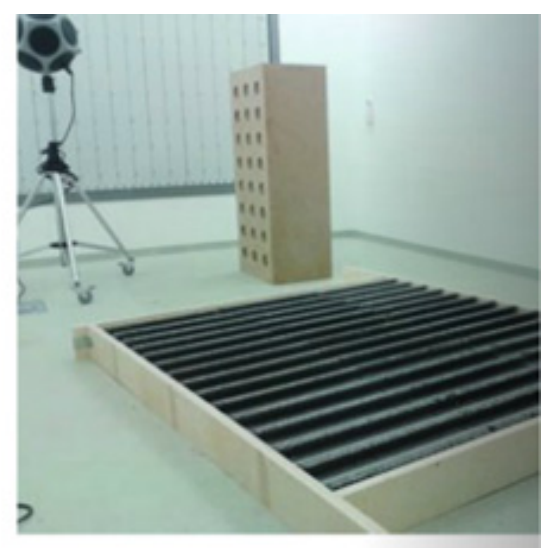

(b) measurement in echo chamber

Figure 6. Degree of sound absorption according to DIN EN ISO 354:2003

\section{Conclusions}

At the completion of this project, a noise barrier was able to be implemented using a textile-reinforced lightweight construction method under construction conditions. In the context of this present research and development project, a scientific basis was created for developing the materials: it was technically implemented in production, tested in numerous test series, adopted and practically investigated in the form of a prototype.

Integrating short fibres in the concrete generated a fine crack pattern with a positive action on durability, amongst other things. Taking the first crack computations into account, proof was furnished in mechanical investigations that the thickness of the textile-reinforced, load-bearing concrete slab can be reduced from $12 \mathrm{~cm}$ (steel reinforced concrete) to $5 \mathrm{~cm}$ (carbon reinforced concrete). Proof was also given of good post-cracking strength, low creep and shrinkage deformation, low susceptibility to cracking and excellent resistance to frost/de-icing salt (exposure class XF4).

This new type of textile-reinforced noise barrier meets requirements as regards resource efficiency, cost reduction, sustainability, minimization of the system slab weight and a decrease in transport and assembly expenses in practice under construction conditions.

The marginal conditions for manufacturing such noise barriers on an industrial scale in large quantities with high demands on equality are currently being created in preparation for its mass production and market launch. Beyond this, a key priority is obtaining general building authority approval or product approval.

\section{Acknowledgements}

This work was supported by the German Federation of Industrial Research Associations (AiF). The authors would like to acknowledge with gratitude the foundation's financial support. The publication costs of this article were funded by the German Research Foundation/DFG (Geschäftszeichen INST 270/219-1) and the Chemnitz University of Technology in the funding programme Open Access Publishing.

\section{References}

Brameshuber, W. (2006). Textile Reinforced Concrete. RILEM Report 36. State-of-the-Art Report of RILEM Technical Committee, TC 201-TRC, 2006.

Curbach, M., \& Jesse, F. (2010). Verstärken mit Textilbeton. In K. Bergmeister, F. Fingerloos, \& J.-D. Wörner (Eds.), Betonkalender 2010. Teil 1, Abschn. VII. Berlin: Ernst \& Sohn. 
Curbach, M., \& Scheerer, S. (2011). Concrete light - Possibilities and Visions. In V. Šrůma (Ed.), Proceedings of the fib Symposium Prague 2011: Concrete Engineering for Excellence and Efficiency (pp. 29-44). 8-10. June 2011, DVD-ROM.

Curbach, M., Michler, H., Weiland, S., \& Jesse, D. (2008). Textilbewehrter Beton-Innovativ! Leicht! Formbar! Z. BetonWerk International, 11(5), 62-72.

Curbach, M., Scheerer, S. (2012). Wie die Baustoffe von heute das Bauen von morgen beeinflussen. In Baustoffe und Betonbau - Lehren, Forschen, Prüfen, Anwenden (pp. 25-36).

Curbach, M., Scheerer, S., Hampel, T., Schmidt, N., \& Wellner, S. (2013, May). Structural Reassessment of Existing Road Bridges in Germany. In IABSE Symposium Report (Vol. 99, No. 12, pp. 1282-1289). International Association for Bridge and Structural Engineering. http://dx.doi.org/10.2749/2221378138065 01948

Funke, H., Gelbrich, S., \& Ehrlich, A. (2013). A New Hybrid Material of Textile Reinforced Concrete and Glass Fibre Reinforced Plastic. Journal of Materials Science Research, 2(3), 96-102. http://dx.doi.orrg/10.5539/ jmsr.v2n3p96

Funke, H., Gelbrich, S., \& Ehrlich, A. (2013). Development of a new hybrid material of textile reinforced concrete and glass fibre reinforced plastic. Procedia Materials Science, 2, 103-110. http://dx.doi.org/10. 1016/j.mspro.2013.02.013

Lohre, D., Bemecker, T., \& Stock, W. (2012). ZF-Zukunftsstudie 2012. In EuroTransport Media Verlags- und Veranstaltungs-GmbH. Stuttgart, S. 17.

Mobasher, B., Dey, V., Cohen, Z., \& Peled, A. (2014). Correlation of constitutive response of hybrid textile reinforced concrete from tensile and flexural tests. Cement and Concrete Composites, 53, 148-161. http://dx.doi.org/10.1016/j. cemconcomp.2014.06.004

\section{Copyrights}

Copyright for this article is retained by the author(s), with first publication rights granted to the journal.

This is an open-access article distributed under the terms and conditions of the Creative Commons Attribution license (http://creativecommons.org/licenses/by/3.0/). 